\title{
ANALIZA PORÓWNAWCZA HIPOTECZNYCH RENT MAŁŻEŃSKICH W KRAJACH UNII EUROPEJSKIEJ ${ }^{1}$
}

ŚLĄSKI

PRZEGLĄD

STATYSTYCZNY

Nr 13(19)

ISSN 1644-6739

e-ISSN 2449-9765

Uniwersytet Ekonomiczny we Wrocławiu

DOI: $10.15611 /$ sps.2015.13.07

Streszczenie: Społeczeństwo żyje coraz dłużej, a emerytury pobierane z systemu ubezpieczeń społecznych są niskie, dlatego na rynku pojawiają się produkty umożliwiające pozyskanie dodatkowych środków finansowych, aby emeryci mogli zachować dotychczasowy standard życia. Jednym z takich produktów jest tzw. renta hipoteczna. W sytuacji, gdy właścicielami nieruchomości są małżonkowie istnieje możliwość wypłacania tzw. rent małżeńskich, gdy oboje małżonkowie żyją, a także gdy jedno z nich umiera. Celem artykułu jest analiza porównawcza wielkości świadczeń rentowych wynikających z zakupu małżeńskiej renty hipotecznej w krajach Unii Europejskiej, a w szczególności ustalenie zakresu wielkości rat renty. Do analizy wysokości świadczeń rentowych zostały wybrane kraje, w których przyszły czas trwania życia mężczyzn i kobiet jest najkrótszy i najdłuższy dla ustalonej grupy wiekowej małżonków. Ponadto analizowano wysokość renty w krajach, w których bezwzględna różnica między czasem trwania życia małżonków jest najmniejsza i największa. Polska okazała się krajem, w którym przyszły czas trwania życia kobiet i mężczyzn oraz różnica między tymi wielkościami są typowe, dlatego została uwzględniona w analizie. W celu uproszczenia zapisu i obliczeń numerycznych wykorzystano macierzową reprezentację formuł na wyznaczenie wysokości świadczeń rentowych. Wszystkie obliczenia wykonano na podstawie Tablic trwania życia z 2009 r., przy użyciu własnych interfejsów napisanych w programie MATLAB.

Słowa kluczowe: małżeńska renta hipoteczna, status wspólnego życia, status ostatniego przeżywającego, model wielostanowy.

\section{Wstęp}

Społeczeństwo żyje coraz dłużej. Emerytury pobierane z systemu ubezpieczeń społecznych są niskie. W związku z tym na rynku pojawiają się produkty umożliwiające osobom w wieku emerytalnym pozyskanie dodatkowych środków finansowych na podtrzymanie dotychczasowego standardu życia. Jednym $\mathrm{z}$ takich produktów jest renta hipoteczna (ang. reverse annuity contract). Zgodnie $\mathrm{z}$ umową właściciel mieszkania lub domu, w zamian za przeniesienie praw własności na firmę zainteresowaną nabyciem takiej nieruchomości, będzie

\footnotetext{
${ }^{1}$ Praca finansowana z grantu 2013/09/B/HS4/00490.
} 
otrzymywać dożywotnią lub terminową rentę. W sytuacji, gdy właścicielami nieruchomości są małżonkowie, istnieje możliwość wypłacania rent małżeńskich. Istnieją dwa rodzaje małżeńskiej renty hipotecznej, zróżnicowane ze względu na typ świadczeń rentowych. Pierwsza z nich wypłacana jest wtedy, gdy oboje małżonkowie żyją. Druga renta wypłacana jest wówczas, gdy jeden z małżonków umiera.

Celem artykułu jest analiza porównawcza wielkości świadczeń rentowych netto w krajach Unii Europejskiej w przypadku małżeńskiej renty hipotecznej. Pominięte zostały wszelkie koszty związane z zawarciem i obsługą umowy. Analizowany jest jedynie wpływ tablic trwania życia na wysokości świadczeń rentowych przy założeniu, że przyszłe czasy trwania życia męża i żony są niezależne. Do analizy wysokości rat rent wybrano kraje, w których przyszły czas trwania życia był najdłuższy lub najkrótszy w poszczególnych grupach wiekowych. W wyborze uwzględniono także różnice między przyszłym czasem trwania życia małżonków. Pozwoliło to na określenie zakresu wysokości rat renty małżeńskiej w krajach UE oraz zbadanie wpływu różnicy wieku między małżonkami na wysokość świadczenia w zależności od rodzaju umowy. Analiza została dokonana w oparciu o rozbudowany model wielostanowy umożliwiający wykorzystanie do obliczeń numerycznych macierzowej reprezentacji wzorów na wysokości świadczeń rentowych (por. [Dębicka i Marciniuk 2014]). Wszystkie obliczenia wykonano przy użyciu własnych interfejsów napisanych w programie MATLAB.

Artykuł, oprócz wstępu stanowiącego paragraf 1, zbudowany jest $\mathrm{z}$ trzech paragrafów. W paragrafie 2 scharakteryzowano rodzaje małżeńskiej renty hipotecznej. Ponadto przedstawiono model wielostanowy wykorzystany do modelowania opisanych umów wraz z reprezentacją macierzową wzorów na świadczenia rentowe. Wybór krajów UE do analizy porównawczej wielkości aktuarialnych został omówiony w paragrafie 3 . Wyboru dokonano na podstawie przeciętnego dalszego czasu trwania życia mężczyzn i kobiet w roku 2009. Paragraf 4 zawiera wyniki badań, a ich podsumowanie przedstawiono w paragrafie 5 .

\section{Małżeńska renta hipoteczna}

Renta hipoteczna (ang. reverse annuity contract) jest to terminowe lub dożywotnie świadczenie, które właściciel nieruchomości może otrzymać w zamian za przeniesienie praw własności na specjalnie w tym celu utworzony Fundusz Hipoteczny, gwarantując sobie w akcie nota- 
rialnym prawo do mieszkania w danym lokalu do śmierci. Renta hipoteczna oferowana jest w Polsce od 2005 r. ludziom starszym, jedynie $\mathrm{w}$ formie indywidualnej. Przeniesienie praw własności na fundusz STATYSTYCZNY następuje już po podpisaniu aktu notarialnego. Zabezpieczeniem tej transakcji, jak również wypłacania renty, jest wpis w dziale IV ksiąg wieczystych. Bezpieczeństwo klientów regulowane jest jedynie kodeksem cywilnym, a w razie bankructwa funduszu pozostaje dochodzenie swoich praw jedynie na drodze sądowej (por. [Borys 2013]).

Właścicielami nieruchomości są często małżonkowie, dlatego warto rozważyć wprowadzenie na rynek małżeńskiej renty hipotecznej. Można wyróżnić dwa rodzaje renty małżeńskiej (por. [Marciniuk 2014]):

- status wspólnego życia (w skrócie SWŻ) - małżeńską rentę hipoteczną, która wypłacana jest jedynie do momentu śmierci pierwszego z małżonków,

- status ostatniego przeżywającego (w skrócie SOP) - małżeńską rentę hipoteczną, która wypłacana jest do momentu śmierci drugiego małżonka.

Hipoteczna renta małżeńska jest produktem podobnym do renty małżeńskiej oferowanej przez ubezpieczycieli sprzedających renty życiowe. Dlatego do wyznaczania wszelkich wielkości aktuarialnych mogą być wykorzystywane techniki rozwijane dla ubezpieczeń wielostanowych. Renty małżeńskie można opisać, używając modelu wielostanowego, wykorzystywanego $\mathrm{w}$ teorii ubezpieczeń do modelowania ubezpieczeń wieloopcyjnych (por. [Dębicka 2012; Dębicka 2013]). Model wielostanowy to para dwóch zbiorów $(S, T)$, gdzie $S=\{1,2, \ldots, N\}$ nazywa się przestrzenią stanów i oznacza wszystkie możliwe zdarzenia losowe związane $\mathrm{z}$ realizacją umowy. Natomiast $T$ jest zbiorem wszystkich możliwych bezpośrednich przejść między stanami. Bezpośrednie przejście ze stanu $i$ do stanu $j$ oznaczane jest w postaci pary $(i, j)$, gdzie $i \neq j$ oraz $i, j \in S$.

Model wielostanowy dla hipotetycznej renty małżeńskiej ma następującą postać (por. [Dickson i in. 2009])

$$
(S, T)=(\{1,2,3,4\},\{(1,2),(1,3),(1,4),(2,4),(3,4)\}),
$$

gdzie elementy przestrzeni stanów oznaczają, że

1 - oboje małżonkowie żyją,

2 - mąż nie żyje,

3 - żona nie żyje,

4 - oboje małżonkowie nie żyją. 
Schemat modelu wielostanowego hipotetycznej renty małżeńskiej został przedstawiony na rys. 1, gdzie okręgi symbolizują elementy przestrzeni stanów $S$, a strzałki bezpośrednie przejścia między nimi należące do zbioru $T$.

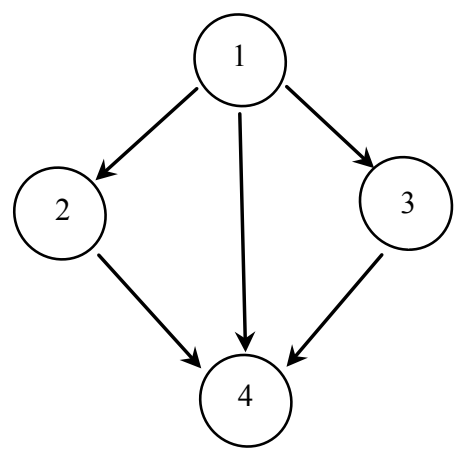

Rys. 1. Schemat modelu wielostanowego hipotecznej renty małżeńskiej Źródło: [Dickson i in. 2009].

Niech dla danej umowy renty hipotecznej, reprezentowanej przez model wielostanowy $(S, T)$, funkcja $X(t) \in S$ oznacza, że małżonków w chwili $t$ (będącej czasem, jaki upłynął od rozpoczęcia umowy) dotyczy przypadek życiowy, któremu został przypisany stan należący do przestrzeni stanów $S$. Ze względu na zastosowania w praktyce, rozważany jest model dyskretny, gdzie płatności są realizowane na początku jednostek czasu, na jaki został podzielony okres wypłaty renty przewidziany w umowie. Wtedy $\{X(t): t=0,1,2, \ldots\}$ jest procesem stochastycznym przyjmującym wartości ze skończonej przestrzeni stanów $S$. Zakładamy, że w jednej jednostce czasu proces $\{X(t)\}$ może zmienić stan tylko jeden raz (może zajść tylko jedno zdarzenie losowe). Umowa renty hipotecznej jest zawarta w chwili 0, a stan oznaczony numerem 1 oznacza stan początkowy, tzn. $X(0)=1$. Ponadto niech $n$ oznacza okres, na jaki została zawarta terminowa małżeńska renta hipoteczna. Dla dożywotniej małżeńskiej renty hipotecznej przyjmujemy, że $n=\omega-\max \left(x_{m}, x_{k}\right)$ dla SWŻ oraz $n=\omega-\min \left(x_{m}, x_{k}\right)$ dla SOP, gdzie $\omega$ jest maksymalnym czasem życia (obecnie $\omega=110$ lat zarówno dla kobiet jak i dla mężczyzn), 
$x_{m}$ oznacza wiek mężczyzny, a $x_{k}$ wiek kobiety w momencie podpisywania umowy (tzw. wiek wstępu).

W celu wyznaczenia wysokości raty renty małżeńskiej niezbędne jest określenie struktury probabilistycznej modelu wielostanowego hipotecznej renty małżeńskiej. Struktura probabilistyczna została określona przy następujących założeniach:

- przyszłe czasy trwania życia męża i żony są niezależne,

- $\{X(t): t=0,1,2, \ldots\}$ jest niejednorodnym łańcuchem Markowa.

Dla dowolnej chwili $t=0,1,2, \ldots, n$ niech dany będzie wektor $\mathbf{P}(t)=\left(P_{1}(t), P_{2}(t), P_{3}(t), P_{4}(t)\right)^{T}$ prawdopodobieństw bycia procesu $\{X(t)\}$ w określonym stanie, gdzie $P_{i}(t)=P(X(t)=i)$. Przy założeniu, że proces $\{X(t)\}$ jest niejednorodnym łańcuchem Markowa, mamy, że $\mathbf{P}^{T}(t)=\mathbf{P}^{T}(0) \prod_{k=0}^{t-1} \mathbf{Q}(k)$, gdzie $\mathbf{P}(0)=(1,0,0,0)^{T}$ jest wektorem rozkładu początkowego, a $\{\mathbf{Q}(k)\}_{k=0}^{n-1}$ jest ciągiem macierzy prawdopodobieństw przejść o elementach zdefiniowanych w następujący sposób $q_{i j}(k)=P(X(k+1)=j \mid X(k)=i)$ (por. [Dębicka 2012]). Dla małżeńskiej renty hipotecznej macierze $\{\mathbf{Q}(k)\}_{k=0}^{n-1}$ są postaci

$$
\mathbf{Q}(k)=\left(\begin{array}{cccc}
p_{x_{k}+k} \cdot p_{x_{m}+k} & p_{x_{k}+k} \cdot q_{x_{m}+k} & q_{x_{k}+k} \cdot p_{x_{m}+k} & q_{x_{k}+k} \cdot q_{x_{m}+k} \\
0 & p_{x_{k}+k} & 0 & q_{x_{k}+k} \\
0 & 0 & p_{x_{m}+k} & q_{x_{m}+k} \\
0 & 0 & 0 & 1
\end{array}\right),
$$

gdzie $p_{x+k}=1-q_{x+k}$ oznacza prawdopodobieństwo przeżycia 1 roku przez osobę w wieku $x$. Prawdopodobieństwa $p_{x_{k}+k}, p_{x_{m}+k}$ odczytuje się bezpośrednio z tablic trwania życia odpowiednio dla kobiet i mężczyzn.

W wyniku realizacji zawartej umowy powstają określone płatności (tj. składki i świadczenia), które tworzą strumienie finansowe. W przypadku hipotecznej renty małżeńskiej strumień składek jest jednoelementowy. Tworzy go jednorazowa składka płacona w ustalonym momencie 0 , oznaczona przez $\pi_{1}(0)$, która jest równa określonemu procentowi $\alpha$ wartości nieruchomości $W, \alpha \in(0 \%, 50 \%$ ], (por. 
[Borys 2013]). Natomiast strumień świadczeń tworzą raty renty płaNr 13(19) conej z góry w momencie $t$ za okres $[t, t+1)$, gdy $X(t)=j$ oznaczonej symbolem $\ddot{b}_{j}(t)$. Rodzaj hipotecznej renty małżeńskiej jest definiowany przez strumień świadczeń wynikających z realizacji umowy w następujący sposób:

- dla SWŻ

$$
\ddot{b}_{j}(k)=\left\{\begin{array}{ll}
\ddot{b}_{1}(k) & \text { dla } j=1 \text { i } k=0,1, \ldots, n-1 \\
0 & \text { poza tym }
\end{array},\right.
$$

- dla SOP

$$
\ddot{b}_{j}(k)=\left\{\begin{array}{ll}
\ddot{b_{1}}(k) & \text { dla } j=1 \text { i } k=0,1, \ldots, n-1 \\
\ddot{b_{2}}(k) & \text { dla } j=2 \text { i } k=1, \ldots, n-1 \\
\ddot{b_{3}}(k) & \text { dla } j=3 \text { i } k=1, \ldots, n-1 \\
0 & \text { poza tym }
\end{array} .\right.
$$

Do wyznaczenia wysokości stałej raty renty wykorzystane zostały formuły macierzowe, które zostały wyprowadzone w [Dębicka i Marciniuk manuscript], przy założeniu, że spełniona jest zasada równoważności oraz przyszłe czasy trwania życia męża i żony są niezależne. Zastosowanie zapisu macierzowego jest możliwe jedynie dla zmodyfikowanego modelu wielostanowego $\left(S^{*}, T^{*}\right)$. Ponieważ w wyniku umowy hipotecznej renty małżeńskiej nie są wypłacane jednorazowe świadczenia związane ze zmianą stanu (np. z tytułu śmierci jednego współmałżonków), to mamy, że $\left(S^{*}, T^{*}\right)=(S, T)$ (por. [Dębicka 2012; Dębicka 2013]).

Dla SWŻ niech $\ddot{b}_{1}(k)=\ddot{b}$ dla $[k, k+1) \quad(k=0,1, \ldots, n-1)$ oznacza stałą rentę płatną z góry, jeżeli oboje małżonkowie żyją. Wtedy

$$
\ddot{b}=\frac{\mathbf{I}_{1}^{T} \mathbf{C}_{\text {out }} \mathbf{J}_{1}}{\mathbf{I}_{1}^{T} \boldsymbol{\Lambda}^{T}\left(\mathbf{I}-\mathbf{I}_{n+1} \mathbf{I}_{n+1}^{T}\right) \mathbf{D} \mathbf{J}_{1}} .
$$

Natomiast dla SOP gdzie $\ddot{b_{1}}(0)=\ddot{b}$ oraz $\ddot{b}_{1}(k)=\ddot{b}_{2}(k)=\ddot{b}_{3}(k)=\ddot{b}$ dla $[k, k+1) \quad(k=1, \ldots, n-1)$ oznaczają raty stałej renty płatnej $\mathrm{z}$ góry, jeżeli co najmniej jeden z małżonków żyje w momencie $k$, mamy, że 


$$
\ddot{b}=\frac{\mathbf{I}_{1}^{T} \mathbf{C}_{o u t} \mathbf{J}_{1}}{\mathbf{I}_{1}^{T} \boldsymbol{\Lambda}^{T}\left(\mathbf{I}-\mathbf{I}_{n+1} \mathbf{I}_{n+1}^{T}-\mathbf{I}_{1} \mathbf{I}_{1}^{T}\right) \mathbf{D}\left(\mathbf{S}-\mathbf{J}_{4}\right)+1} .
$$

We wzorach (1) i (2) macierz $\mathbf{D} \in R^{(n+1) \times 4}$ związana jest ze strukturą probabilistyczną modelu i określona jest następująco

$$
\mathbf{D}=\left(\begin{array}{c}
\mathbf{P}^{T}(0) \\
\mathbf{P}^{T}(1) \\
\vdots \\
\mathbf{P}^{T}(n)
\end{array}\right)
$$

Ze stopą procentową związana jest macierz $\Lambda \in R^{(n+1) \times(n+1)}$, której elementy $\lambda_{k_{1} k_{2}}$ zawierają wartości średnie funkcji dyskonta $v\left(k_{1}, k_{2}\right)$ i wartości średnie funkcji akumulacji $r\left(k_{1}, k_{2}\right)$. W szczególności dla stałej stopy procentowej

$$
\lambda_{k_{1} k_{2}}=\left\{\begin{array}{ccc}
v\left(k_{2}, k_{1}\right) & \text { dla } & k_{1}>k_{2} \\
1 & \text { dla } & k_{1}=k_{2} . \\
r\left(k_{1}, k_{2}\right) & \text { dla } & k_{1}<k_{2}
\end{array}\right.
$$

Macierz przepływów pieniężnych $\mathbf{C}_{\text {out }} \in R^{(n+1) \times 4}$ jest określona dla Funduszu Hipotecznego, gdzie $\alpha W$ jest wartością nieruchomości, dla której określana jest wysokość renty hipotecznej ( $\alpha$ - procent wartości nieruchomości $W$, którą posiadają małżonkowie) i reprezentuje wydatki (ang. outgo) związane z zakupem hipotecznej renty przez parę małżonków. Niezależnie od rodzaju małżeńskiej renty hipotecznej (SWŻ, czy SOP) macierz przepływów pieniężnych ma następującą postać

$$
\mathbf{C}_{\text {out }}=\left(\begin{array}{cccc}
\alpha W & 0 & 0 & 0 \\
0 & 0 & 0 & 0 \\
\vdots & \vdots & \vdots & \vdots \\
0 & 0 & 0 & 0
\end{array}\right) .
$$

Natomiast $\mathbf{S}=(1,1,1,1)^{T}, \mathbf{J}_{1}=(1,0,0,0)^{T}, \mathbf{J}_{4}=(0,0,0,1)^{T}$, $\mathbf{I}_{k+1}=(0,0, \ldots, \underset{k+1}{1}, \ldots, 0)^{T} \in R^{n+1}$ są wektorami pomocniczymi. 


\section{Wybór krajów Unii Europejskiej}

Nr 13(19)

Celem artykułu jest analiza porównawcza wielkości netto świadczeń rentowych w krajach Unii Europejskiej w przypadku małżeńskiej renty hipotecznej. W szczególności określenie zakresu wielkości świadczeń rentowych w zależności od wieku małżonków i ich narodowości. Rozważania prowadzone są dla kobiet i mężczyzn w wieku 60, 65, 70, 75, 80, 85 lat. Kluczowym aspektem jest określenie kryteriów wyboru krajów należących do UE. Kraje zostały wybrane według następujących kryteriów:

K1. oczekiwane dalsze trwanie życia było najdłuższe lub najkrótsze w grupach wiekowych $(60,65,70,75,80,85$ lat $)$ z podziałem na płeć według tablic trwania życia z 2009 r.,

K2. różnica między oczekiwanym przyszłym trwaniem życia kobiet i mężczyzn najbardziej lub najmniej się różniła w danej grupie wiekowej w 2009 r., przy założeniu, że mężczyzna i kobieta są tej samej narodowości.

Niech $e_{x}^{c}$ oznacza przeciętne dalsze trwanie życia osoby w wieku $x$ pochodzącej z kraju $c$ należącego do UE. Wybór krajów UE do analizy rozpoczęto od wyznaczenia podstawowych parametrów statystyki opisowej dla sześciu 27-elementowych szeregów zawierających $e_{x_{k}}^{c}$ dla kobiet $\left(x_{k} \in\{60,65,70,75,80,85\} \quad\right.$ lat $)$ oraz dla sześciu 27-elementowych szeregów zawierających $e_{x_{m}}^{c}$ dla mężczyzn $\left(x_{m} \in\{60,65,70,75,80,85\} \quad\right.$ lat). Szeregi te zamieszczone zostały w Załączniku 1.

Dla każdego analizowanego wieku zarówno górna, jak i dolna granica przedziału trzy-sigmowego dla kobiet jest większa niż odpowiednia granica dla mężczyzn. Ponadto zauważmy, że dla każdego wieku i obu płci nie istnieją obserwacje odstające, gdyż dla każdego $\mathrm{z}$ analizowanych szeregów wartości najmniejsze $\left(\operatorname{Min}(x)=\min _{c \in U E} e_{x}^{c}\right)$, jak i największe $\left(\operatorname{Max}(x)=\max _{c \in U E} e_{x}^{c}\right)$ mieszczą się w wyznaczonym dla swojego szeregu przedziale trzy-sigmowym.

Zgodnie z kryterium K1 (por. tabela 1 oraz załącznik 1) okazało się, że niezależnie od wieku, najkrótszy przyszły czas trwania życia $(\operatorname{Min}(x))$ miały kobiety żyjące w Bułgarii, a najdłuższy $(\operatorname{Max}(x))$ Francuski. W przypadku mężczyzn najkrótszy przyszły czas trwania życia charakteryzował Litwinów (w wieku $x_{m}=60,65,70,75$ lat) oraz Bułga- 
rów (w wieku $x_{m}=80,85$ lat). Podobnie jak w przypadku kobiet, także

Francuzi (w każdej analizowanej grupie wiekowej) mogli spodziewać $\mathbf{N r}$ 13(19) się najdłuższego przyszłego czasu trwania życia.

Tabela 1. Statystyki dotyczące przeciętnego przyszłego czasu trwania życia kobiet i mężczyzn w roku 2009 w krajach UE

\begin{tabular}{|l|r|r|c|c|c|c|c|c|c|c|c|c|}
\hline \multicolumn{1}{|c|}{ Płeć } & \multicolumn{7}{|c|}{ KOBIETY } & \multicolumn{6}{c|}{ MĘŻCZYŹNI } \\
\hline \multicolumn{1}{|c}{ Wiek } & 60 & 65 & 70 & 75 & 80 & 85 & 60 & 65 & 70 & 75 & 80 & 85 \\
\hline Średnia arytmetyczna & 24,4 & 20,2 & 16,1 & 12,4 & 9,1 & 6,6 & 20,1 & 16,5 & 13,1 & 10,1 & 7,5 & 5,6 \\
\hline Odchylenie standardowe & 1,7 & 1,5 & 1,4 & 1,2 & 0,9 & 0,7 & 2,2 & 1,7 & 1,3 & 0,9 & 0,6 & 0,5 \\
\hline $\begin{array}{l}\text { Dolna granica typowego } \\
\text { obszaru zmienności }\end{array}$ & 22,7 & 18,7 & 14,7 & 11,2 & 8,2 & 6,0 & 17,9 & 14,7 & 11,8 & 9,1 & 6,9 & 5,1 \\
\hline Polska & 23,2 & 19,2 & 15,3 & 11,7 & 8,6 & 6,3 & 17,9 & 14,8 & 11,9 & 9,3 & 7,0 & 5,3 \\
\hline $\begin{array}{l}\text { Górna granica typowego } \\
\text { obszaru zmienności }\end{array}$ & 26,1 & 21,7 & 17,5 & 13,5 & 10,0 & 7,3 & 22,2 & 18,2 & 14,4 & 11,0 & 8,1 & 6,0 \\
\hline $\begin{array}{l}\text { Dolna granica przedziału } \\
\text { trzy-sigmowego }\end{array}$ & 19,4 & 15,6 & 12,0 & 8,9 & 6,3 & 4,6 & 13,6 & 11,3 & 9,2 & 7,3 & 5,6 & 4,1 \\
\hline $\begin{array}{l}\text { Wartość najmniejsza - } \\
\text { Min(x) }\end{array}$ & 21,2 & 17,1 & 13,3 & 9,9 & 7,1 & 5,2 & 15,9 & 13,2 & 10,7 & 8,4 & 6,3 & 4,8 \\
\hline $\begin{array}{l}\text { Wartość największa - } \\
\text { Max(x) }\end{array}$ & 27,5 & 23,2 & 18,9 & 14,9 & 11,2 & 8,2 & 22,5 & 18,7 & 15,1 & 11,7 & 8,8 & 6,5 \\
\hline $\begin{array}{l}\text { Górna granica przedziału } \\
\text { trzy-sigmowego }\end{array}$ & 29,4 & 24,8 & 20,2 & 15,9 & 11,9 & 8,6 & 26,6 & 21,6 & 17,0 & 12,9 & 9,4 & 7,0 \\
\hline
\end{tabular}

Źródło: opracowanie własne.

Polska okazała się krajem, w którym przeciętne dalsze trwanie życia kobiet i mężczyzn w 2009 r. było typowe w każdej z analizowanych grup wiekowych i jako reprezentant grupy krajów o typowym przeciętnym przyszłym czasie trwania życia wybrana została do analizy.

Ponieważ w przypadku małżeńskiej renty hipotecznej wysokość świadczenia zależy od przyszłego czasu trwania życia zarówno żony, jak i męża, to w kolejnej fazie wyboru krajów do analizy podana została bezwzględna różnica przyszłego czasu trwania życia kobiety i mężczyzny tj. $\left|e_{x_{k}}^{c}-e_{x_{m}}^{c}\right|$. Zgodnie z kryterium K2 wybrane zostały te kraje, dla których różnica między przyszłym trwaniem życia kobiet i mężczyzn była największa $\left(\operatorname{Max}\left(x_{k}, x_{m}\right)=\max _{c \in U E}\left|e_{x_{k}}^{c}-e_{x_{m}}^{c}\right|\right)$ lub najmniejsza $\left(\operatorname{Min}\left(x_{k}, x_{m}\right)=\min _{c \in U E}\left|e_{x_{k}}^{c}-e_{x_{m}}^{c}\right|\right)$ w danej grupie wiekowej. Wyniki zostały zamieszczone odpowiednio w tabelach 2 i 3.

W górnej części tabeli 2 w nawiasach znajdują się te kraje, dla których różnica między przeciętnym przyszłym czasem trwania życia kobiet i mężczyzn jest druga (II) lub trzecia (III) w kolejności. Powo- 
dem jest konieczność pominięcia w całej analizie niektórych krajów UE. Mianowicie Estonia została wyłączona z analizy, ze względu na dużą migrację jej mieszkańców na przełomie XX i XXI w. Tablice Trwania Życia dla tego kraju nie odzwierciedlają wiernie jego sytuacji demograficznej. Dodatkowo ze względu na brak dostępu do jednorocznych tablic trwania życia, w analizie pominięte zostały Cypr, Grecja i Rumunia. Ponadto, jeżeli w danej grupie wiekowej dwa kraje miały taką sama różnicę między przyszłym czasem trwania życia żony i męża, wybrany został kraj z dłuższym oczekiwanym przyszłym czasem trwania życia dla kobiet i mężczyzn. Ostateczny wybór krajów został zamieszczony w dolnej części tabeli 2 wraz z bezwzględną różnicą (w latach) między przeciętnym przyszłym czasem trwania życia kobiet i mężczyzn tj. $\operatorname{Max}\left(x_{k}, x_{m}\right)$.

Dolna część tabeli 3 przedstawia ostateczny wybór krajów ze względu na najmniejszą różnicę między przeciętnym przyszłym cza-

Tabela 2. Kraje UE charakteryzujące się największą różnicą między przeciętnym przyszłym czasem trwania życia kobiet i mężczyzn w roku 2009

\begin{tabular}{|c|c|c|c|c|c|c|}
\hline$x_{k} \backslash x_{m}$ & 60 & 65 & 70 & 75 & 80 & 85 \\
\hline 60 & Litwa & \begin{tabular}{|l|}
$\begin{array}{l}\text { Estonia } \\
\text { (II -Litwa) }\end{array}$ \\
\end{tabular} & Francja & Francja & Francja & Francja \\
\hline 65 & Litwa & Litwa & Francja & Francja & Francja & Francja \\
\hline 70 & $\begin{array}{l}\text { Cypr } \\
\text { (II - Grecja, } \\
\text { Szwecja) }\end{array}$ & \begin{tabular}{|l} 
Cypr \\
(II - Estonia, \\
III-Hiszpania)
\end{tabular} & $\begin{array}{l}\text { Estonia } \\
\text { (II - Francja, } \\
\text { Litwa) }\end{array}$ & Francja & Francja & Francja \\
\hline 75 & $\begin{array}{l}\text { Cypr } \\
\text { (II - Grecja, } \\
\text { Szwecja) }\end{array}$ & $\begin{array}{l}\text { Cypr } \\
\text { (II -Hiszpania) }\end{array}$ & $\begin{array}{l}\text { Cypr } \\
\text { (II - Hiszpania, } \\
\text { Luksemburg) }\end{array}$ & Francja & Francja & Francja \\
\hline 80 & $\begin{array}{l}\text { Cypr } \\
\text { (II - Szwecja) }\end{array}$ & $\begin{array}{l}\text { Cypr } \\
\text { (II - Hiszpania) }\end{array}$ & $\begin{array}{l}\text { Cypr } \\
\text { (II - Hiszpania, } \\
\text { Luksemburg) }\end{array}$ & $\begin{array}{l}\text { Rumunia } \\
\text { (II -Luksem- } \\
\text { burg) } \\
\end{array}$ & Luksemburg & Luksemburg \\
\hline 85 & Szwecja & $\begin{array}{l}\text { Grecja } \\
\text { (II - Hiszpania) }\end{array}$ & $\begin{array}{l}\text { Grecja } \\
\text { (II - Luksemburg) }\end{array}$ & $\begin{array}{l}\text { Grecja } \\
\text { (II - Luksem- } \\
\text { burg) }\end{array}$ & $\begin{array}{l}\text { Rumunia } \\
\text { (II - Grecja, } \\
\text { Niemcy) }\end{array}$ & Luksemburg \\
\hline$x_{k} \backslash x_{m}$ & 60 & 65 & 70 & 75 & 8 & 85 \\
\hline 60 & $\begin{array}{l}\text { Litwa } \\
6,5\end{array}$ & $\begin{array}{l}\text { Litwa } \\
9,1\end{array}$ & $\begin{array}{l}\text { Francja } \\
12,4\end{array}$ & $\begin{array}{l}\text { Francja } \\
15,8\end{array}$ & $\begin{array}{l}\text { Francja } \\
18,7\end{array}$ & $\begin{array}{l}\text { Francja } \\
21,0\end{array}$ \\
\hline 65 & $\begin{array}{l}\text { Litwa } \\
2,6\end{array}$ & $\begin{array}{l}\text { Litwa } \\
5,2\end{array}$ & $\begin{array}{l}\text { Francja } \\
8,1\end{array}$ & \begin{tabular}{|l|} 
Francja \\
11,5
\end{tabular} & $\begin{array}{l}\text { Francja } \\
14,4\end{array}$ & $\begin{array}{l}\text { Francja } \\
16,7\end{array}$ \\
\hline 70 & $\begin{array}{l}\text { Szwecja } \\
5,3\end{array}$ & $\begin{array}{l}\text { Hiszpania } \\
7,9\end{array}$ & $\begin{array}{l}\text { Francja } \\
3,8\end{array}$ & \begin{tabular}{|l|} 
Francja \\
7,2
\end{tabular} & $\begin{array}{l}\text { Francja } \\
10,1\end{array}$ & $\begin{array}{l}\text { Francja } \\
12,4\end{array}$ \\
\hline 75 & $\begin{array}{l}\text { Szwecja } \\
9,2\end{array}$ & $\begin{array}{l}\text { Hiszpania } \\
11,2\end{array}$ & $\begin{array}{l}\text { Hiszpania } \\
6,8\end{array}$ & $\begin{array}{l}\text { Francja } \\
3,2\end{array}$ & $\begin{array}{l}\text { Francja } \\
6,1\end{array}$ & $\begin{array}{l}\text { Francja } \\
8,4\end{array}$ \\
\hline 80 & \begin{tabular}{|l|} 
Szwecja \\
12,7 \\
\end{tabular} & $\begin{array}{l}\text { Hiszpania } \\
14,1\end{array}$ & $\begin{array}{l}\text { Hiszpania } \\
9,7\end{array}$ & \begin{tabular}{|l} 
Luksemburg \\
5,9
\end{tabular} & \begin{tabular}{|l} 
Luksemburg \\
2,5
\end{tabular} & $\begin{array}{l}\text { Luksemburg } \\
4,9\end{array}$ \\
\hline 85 & \begin{tabular}{|l} 
Szwecja \\
15,5 \\
\end{tabular} & $\begin{array}{l}\text { Hiszpania } \\
16,3\end{array}$ & $\begin{array}{l}\text { Luksemburg } \\
12,1\end{array}$ & \begin{tabular}{|l} 
Luksemburg \\
8,3
\end{tabular} & \begin{tabular}{|l|} 
Niemcy \\
1,5 \\
\end{tabular} & \begin{tabular}{|l} 
Luksemburg \\
2,3
\end{tabular} \\
\hline
\end{tabular}

Źródło: opracowanie własne. 
sem trwania życia kobiet i mężczyzn dla poszczególnych grup wiekowych wraz $\mathrm{z}$ bezwzględną różnica (w latach) między przeciętnym przyszłym czasem trwania życia kobiet i mężczyzn tj. $\operatorname{Min}\left(x_{k}, x_{m}\right)$. Podobnie jak w tabeli 2, w analizie pominięto Cypr i Rumunię. Natomiast, jeżeli w danej grupie wiekowej dwa kraje miały taką sama różnicę między przyszłym czasem trwania życia kobiety i mężczyzny, wybrano kraj z krótszym oczekiwanym przyszłym czasem trwania życia dla obu płci.

Tabela 3. Kraje UE charakteryzujące się najmniejszą różnicą między przeciętnym przyszłym czasem trwania życia kobiet i mężczyzn w roku 2009

\begin{tabular}{|c|c|c|c|c|c|c|}
\hline$x_{k} x_{m}$ & 60 & 65 & 70 & 75 & 80 & 85 \\
\hline 60 & $\begin{array}{l}\text { Wielka Brytania, } \\
\text { Dania }\end{array}$ & Dania & $\begin{array}{l}\text { Rumunia } \\
\text { (II - Bułgaria) }\end{array}$ & $\begin{array}{l}\text { Rumunia } \\
\text { (II - Bułgaria) }\end{array}$ & $\begin{array}{l}\text { Rumunia } \\
\text { (II - Bułgaria) }\end{array}$ & $\begin{array}{l}\text { Rumunia } \\
\text { (II - Bułgaria) }\end{array}$ \\
\hline 65 & $\begin{array}{l}\text { Bułgaria, } \\
\text { Czechy, } \\
\text { Luksemburg }\end{array}$ & $\begin{array}{l}\text { Wielka } \\
\text { Brytania, } \\
\text { Dania }\end{array}$ & $\begin{array}{l}\text { Rumunia } \\
\text { (II - Bułgaria) }\end{array}$ & $\begin{array}{l}\text { Rumunia } \\
\text { (II - Bułgaria) }\end{array}$ & $\begin{array}{l}\text { Rumunia } \\
\text { (II - Bułgaria) }\end{array}$ & $\begin{array}{l}\text { Rumunia } \\
\text { (II - Bułgaria) }\end{array}$ \\
\hline 70 & Litwa & $\begin{array}{l}\text { Słowenia, } \\
\text { Słowacja }\end{array}$ & $\begin{array}{l}\text { Rumunia } \\
\text { (II - Cypr, } \\
\text { III - Bułgaria) }\end{array}$ & $\begin{array}{l}\text { Rumunia } \\
\text { (II - Bułgaria) }\end{array}$ & $\begin{array}{l}\text { Rumunia } \\
\text { (II - Bułgaria) }\end{array}$ & $\begin{array}{l}\text { Rumunia } \\
\text { (II - Bułgaria) }\end{array}$ \\
\hline 75 & Litwa & Litwa & $\begin{array}{l}\text { Francja, } \\
\text { Litwa, } \\
\text { Węgry }\end{array}$ & $\begin{array}{l}\text { Rumunia } \\
\text { (II - Bułgaria, } \\
\text { Cypr) }\end{array}$ & $\begin{array}{l}\text { Rumunia } \\
\text { (II - Bułgaria) }\end{array}$ & $\begin{array}{l}\text { Rumunia } \\
\text { (II - Bułgaria) }\end{array}$ \\
\hline 80 & Litwa & Lotwa & Lotwa & Lotwa & $\begin{array}{l}\text { Rumunia } \\
\text { (II - Bułgaria) }\end{array}$ & $\begin{array}{l}\text { Rumunia } \\
\text { (II - Bułgaria) }\end{array}$ \\
\hline 85 & Łotwa & Łotwa & Lotwa & Lotwa & Luksemburg & $\begin{array}{l}\text { Bułgaria, } \\
\text { Niemcy }\end{array}$ \\
\hline$x_{k} \backslash x_{m}$ & 60 & 65 & 70 & 75 & 80 & 85 \\
\hline 60 & $\begin{array}{l}\text { Dania } \\
3,0\end{array}$ & $\begin{array}{l}\text { Dania } \\
6,8\end{array}$ & $\begin{array}{l}\text { Bułgaria } \\
10,1\end{array}$ & $\begin{array}{l}\text { Bułgaria } \\
12,7\end{array}$ & $\begin{array}{l}\text { Bułgaria } \\
14,9\end{array}$ & $\begin{array}{l}\text { Bułgaria } \\
16,4\end{array}$ \\
\hline 65 & $\begin{array}{l}\text { Luksemburg } \\
0,1\end{array}$ & $\begin{array}{l}\text { Dania } \\
2,7 \\
\end{array}$ & $\begin{array}{l}\text { Bułgaria } \\
6,0\end{array}$ & $\begin{array}{l}\text { Bułgaria } \\
8,6\end{array}$ & $\begin{array}{l}\text { Bułgaria } \\
10,8\end{array}$ & $\begin{array}{l}\text { Bułgaria } \\
12,3\end{array}$ \\
\hline 70 & $\begin{array}{l}\text { Litwa } \\
1,2\end{array}$ & $\begin{array}{l}\text { Słowacja } \\
0\end{array}$ & $\begin{array}{l}\text { Bułgaria } \\
2,2\end{array}$ & $\begin{array}{l}\text { Bułgaria } \\
4,8\end{array}$ & $\begin{array}{l}\text { Bułgaria } \\
7,0\end{array}$ & $\begin{array}{l}\text { Bułgaria } \\
8,5\end{array}$ \\
\hline 75 & $\begin{array}{l}\text { Litwa } \\
4,8\end{array}$ & $\begin{array}{l}\text { Litwa } \\
2,2\end{array}$ & $\begin{array}{l}\text { Węgry } \\
0,2\end{array}$ & $\begin{array}{l}\text { Bułgaria } \\
1,4\end{array}$ & $\begin{array}{l}\text { Bułgaria } \\
3,6\end{array}$ & $\begin{array}{l}\text { Bułgaria } \\
5,1\end{array}$ \\
\hline 80 & $\begin{array}{l}\text { Litwa } \\
7,8\end{array}$ & $\begin{array}{l}\text { Lotwa } \\
5,2\end{array}$ & $\begin{array}{l}\text { Lotwa } \\
2,7\end{array}$ & $\begin{array}{l}\text { Łotwa } \\
0,3\end{array}$ & $\begin{array}{l}\text { Bułgaria } \\
0,8\end{array}$ & $\begin{array}{l}\text { Bułgaria } \\
2,3\end{array}$ \\
\hline 85 & $\begin{array}{l}\text { Lotwa } \\
10,0\end{array}$ & $\begin{array}{l}\text { Lotwa } \\
7,3\end{array}$ & $\begin{array}{l}\text { Lotwa } \\
4,8\end{array}$ & $\begin{array}{l}\text { Lotwa } \\
2,5\end{array}$ & $\begin{array}{l}\text { Luksemburg } \\
0,1\end{array}$ & $\begin{array}{l}\text { Bułgaria } \\
0,4\end{array}$ \\
\hline
\end{tabular}

Źródło: opracowanie własne.

Bazując na powyżej dokonanym wyborze, w paragrafie 4 przeprowadzono analizę zakresu różnic między wysokością świadczeń wynikających z realizacji umowy małżeńskiej renty hipotecznej. 


\section{Przykłady numeryczne}

Nr 13(19)

Przykłady numeryczne, zaprezentowane w tym punkcie, wykonane są za pomocą własnych interfejsów, napisanych w programie MATLAB. Do obliczeń przyjęto, że $W=100000$ oraz $\alpha=50 \%$. Wyliczone $\mathrm{w}$ przykładach tego paragrafu wielkości świadczeń są traktowane jako swego rodzaju wskaźnik taryfowy i odpowiadają wielkości świadczenia przypadającego na każde 100000 wartości nieruchomości (dla $\alpha=0,5)$. W przypadku, gdy rzeczywista wartość nieruchomości wynosi $W_{1}$, wystarczy przemnożyć otrzymane wyniki przez $W_{1} \cdot W^{-1}$. Prawdopodobieństwa przeżycia wyznaczone zostały na podstawie Tablic Trwania Życia z 2009 r. dla poszczególnych państw, wchodzących w skład UE, dostępnych na stronie www.mortality.org. Do obliczeń zastosowano stałą stopę procentową $i=3,79 \%$, jako długoterminową stopę procentową $\mathrm{w}$ modelu Svenssona, uzyskaną na podstawie rzeczywistych danych z rynku polskiego (por. [Dębicka i Marciniuk 2014; Marciniuk 2009]). Przedstawione przykłady obliczone są dla osób w wieku 60, 65, 70, 75, 80, 85 lat.

Analiza otrzymanych wyników została podzielona na dwie części. Pierwsza część dotyczy analizy wysokości świadczeń rentowych dla małżeństw pochodzących z krajów UE, wybranych zgodnie z kryterium K1. Druga część analizy dotyczy rat rent wyznaczonych dla krajów UE, wybranych na podstawie kryterium K2.

Rysunek 2 przedstawia stałe roczne świadczenia rentowe w zależności od wieku kobiet i mężczyzn oraz rodzaju renty hipotecznej określonych dla małżeństw francuskich (najdłużej żyjących), polskich (o typowym przeciętnym przyszłym czasie trwania życia) i najkrócej żyjących tj. mieszanych bułgarsko-łotewskich (kobieta w dowolnym wieku, mężczyzna do 75 lat) i bułgarskich (dla mężczyzn po 75. roku życia).

Na rys. 3 przedstawione zostały wysokości rocznych świadczeń w przypadku rent hipotecznych obu rodzajów dla małżeństw najdłużej, najkrócej i typowo żyjących, gdy małżonkowie są równolatkami $\left(x_{k}=x_{m}\right)$. Na rys. 3 liczby w nawiasach oznaczają odpowiedni wiek żony i męża tj. $\left(x_{k} ; x_{m}\right)$. Należy zauważyć, że świadczenie $\mathrm{w}$ obu rodzajach rent hipotecznych rośnie wraz $\mathrm{z}$ wiekiem małżonków. W przypadku SWŻ większy wpływ na wysokość świadczenia ma wiek mężczyzny, w przypadku SOP większy wpływ ma wiek kobiety. Ponadto dla małżeństw w każdym wieku pochodzących z kraju z najkrótszym przeciętnym przyszłym czasem trwania życia świadczenie 
jest najwyższe. W przypadku SWŻ przy ustalonym wieku kobiety różnice te wraz ze wzrostem wieku mężczyzn maleją od 33\% do $27 \%$ dla 65 -letniej kobiety i od $48 \%$ do $41 \%$ dla kobiety w wieku 85 lat. STATYSTYCZNY Wraz ze wzrostem wieku kobiety, a przy ustalonym wieku mężczyzny w przypadku SWŻ, różnice w wysokości świadczeń rosną od $33 \%$ do $48 \%$ dla mężczyzny w wieku 65 lat oraz od $27 \%$ do $41 \%$ dla 85-letniego mężczyzny. W przypadku SOP różnice te są nieco niższe i kształtują się na poziomie $28 \%-40 \%$ (rosną wraz z wiekiem mężczyzn przy ustalonym wieku kobiet oraz przy ustalonym wieku mężczyzn rosną, a następnie nieznacznie maleją).
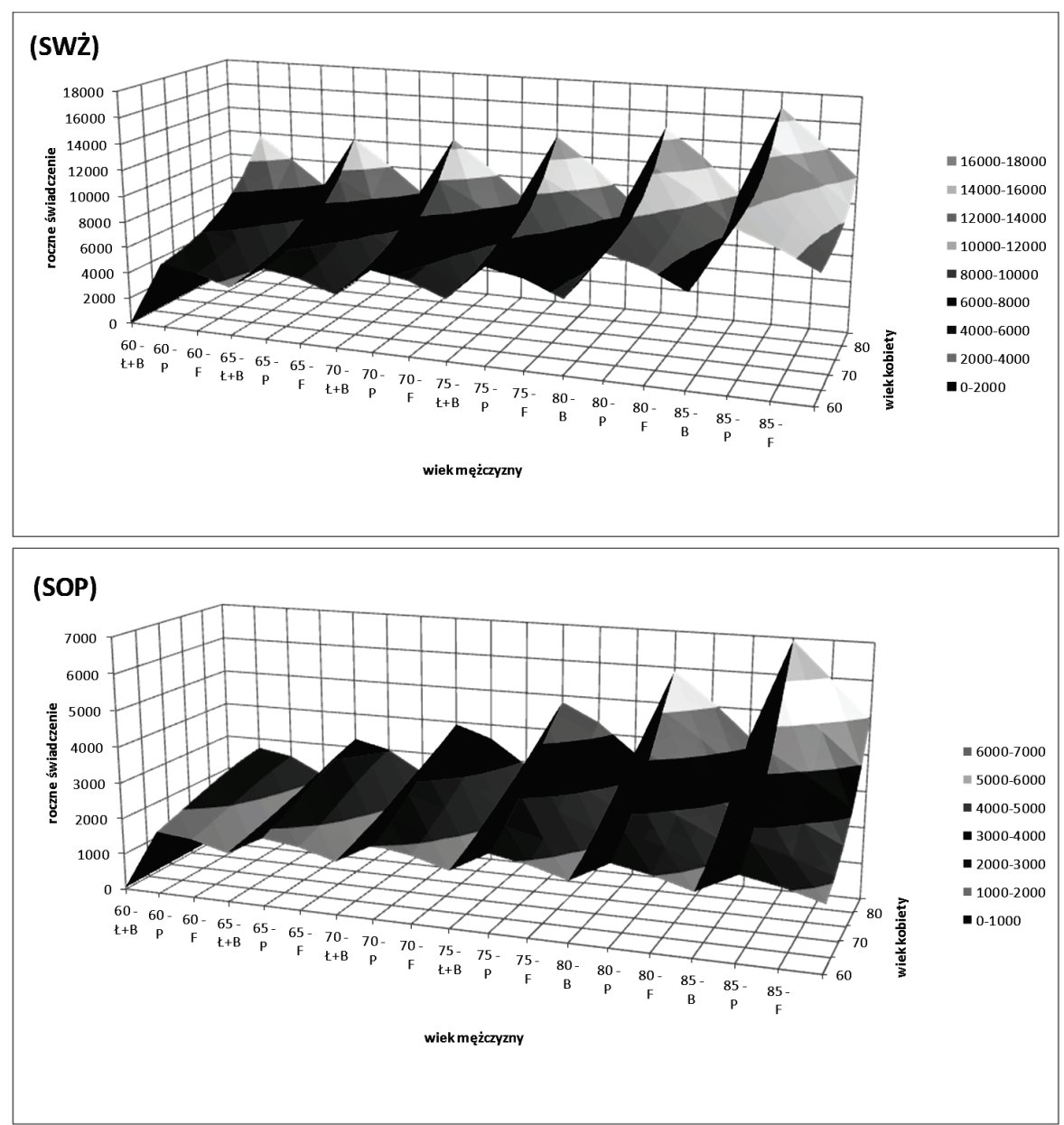

Rys. 2. Roczne świadczenie dla małżeństw francuskich (F), polskich (P) i mieszanych łotewsko-bułgarskich $(\mathrm{L}+\mathrm{B})$ oraz bułgarskich (B)

Źródło: opracowanie własne. 


\section{(SWŻ)}

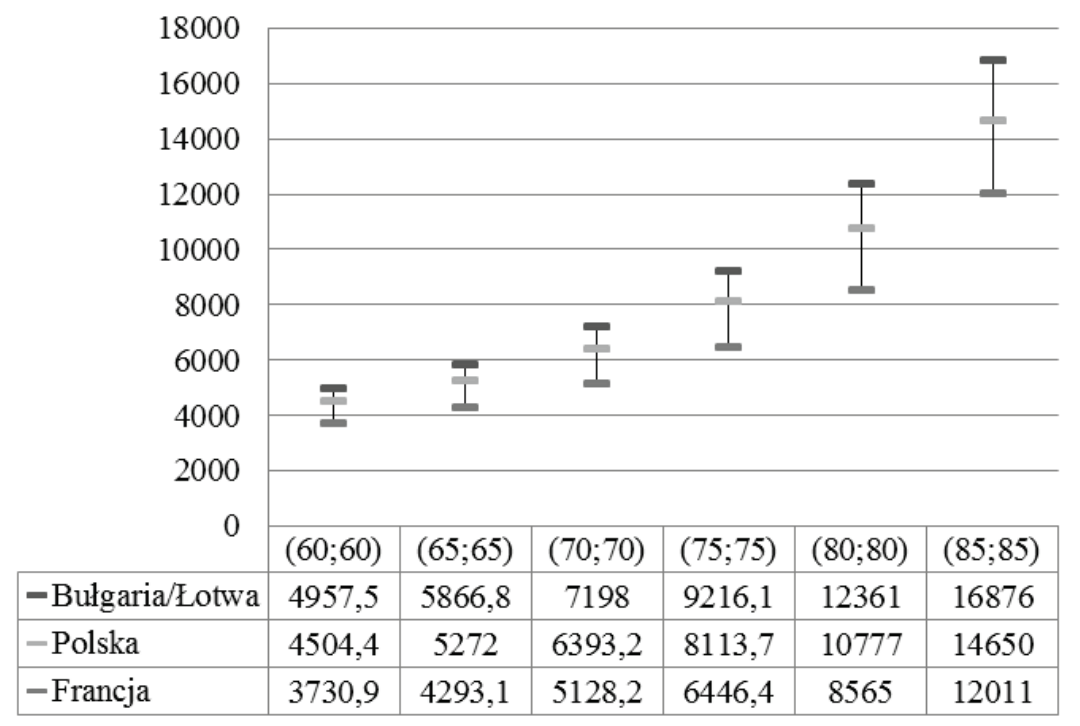

\section{(SOP)}

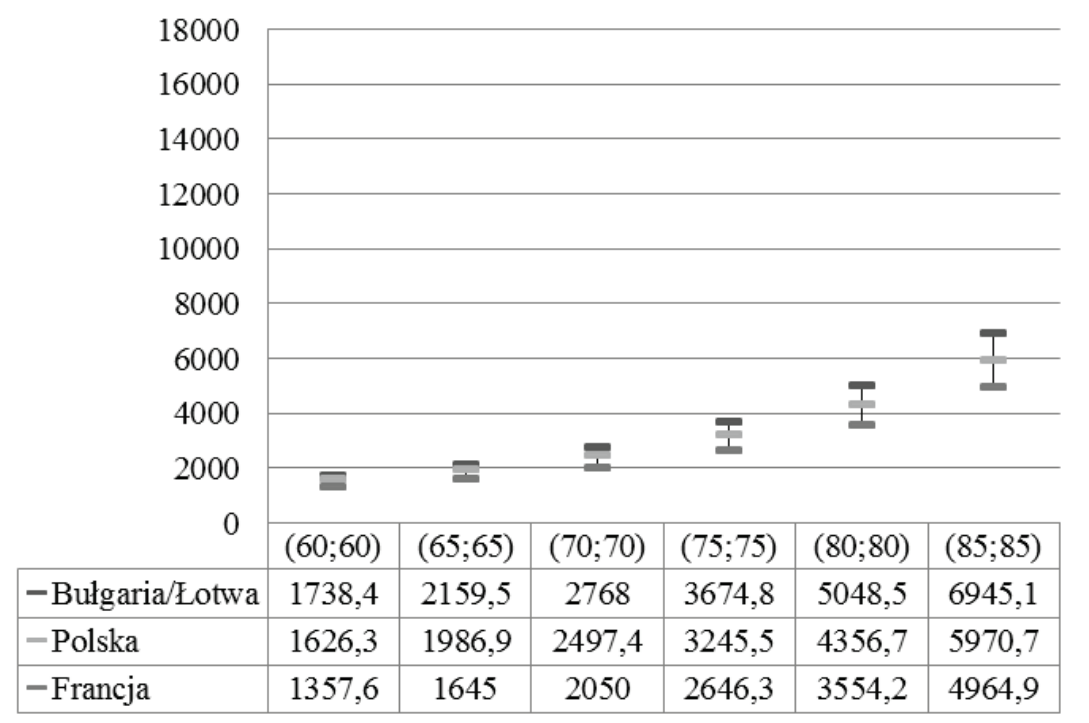

Rys. 3. Zakres wielkości rocznych świadczeń w krajach UE dla małżeństw równolatków Źródło: opracowanie własne. 


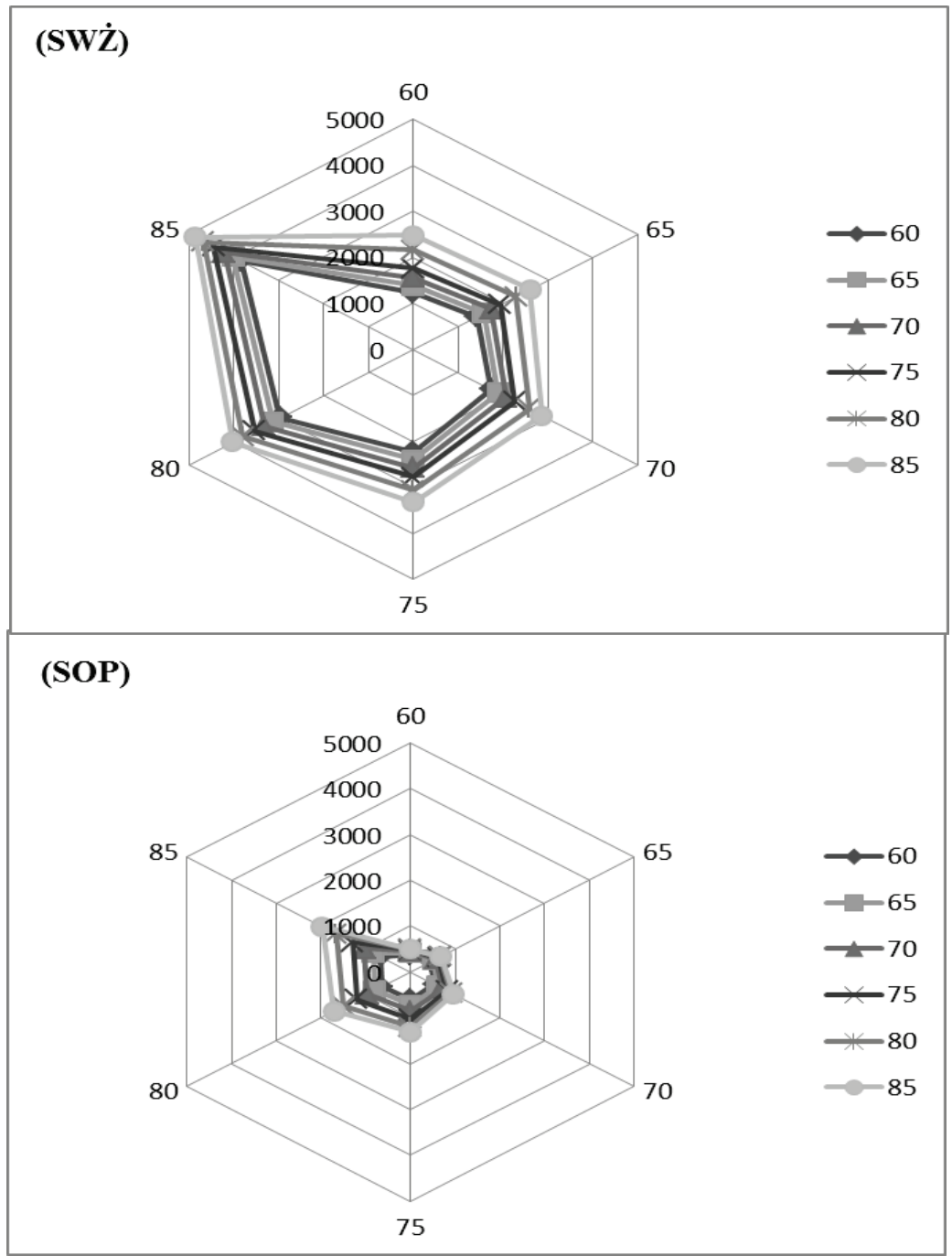

Rys. 4. Różnica między wysokością raty renty w krajach z najkrótszym i najdłuższym przyszłym czasie trwania życia (ramiona siatki - wiek kobiet; linie na których rozpina się pajęczyna - wiek mężczyzn)

Źródło: opracowanie własne.

Niezależnie od wieku małżonków, świadczenia wynikające $\mathrm{z}$ umowy renty hipotecznej rodzaju SWŻ są wyższe niż te, określone dla renty hipotecznej rodzaju SOP. Zakres zmienności świadczeń między małżeństwem z Francji (najdłuższy przeciętny przyszły czas trwania życia) a Bułgarii lub Bułgarii i Łotwy (najkrótszy przeciętny 
przyszły czas trwania życia) w przypadku SWŻ jest dużo większy niż Nr 13(19) w przypadku SOP, co wyraźnie można zaobserwować na rys. 4.

Analizie poddano również wyniki dotyczące wysokości świadczeń rentowych dla małżeństw pochodzących z krajów, gdzie są największe lub najmniejsze bezwzględne różnice między oczekiwanym przyszłym trwaniem życia żony i męża przy założeniu, że małżonkowie pochodzą z tego samego kraju (por. tabele 2 i 3 ).

$\mathrm{Na}$ rys. 5 przedstawiono wartości świadczeń $\ddot{b}^{\left[\operatorname{SWŻ,Max}\left(x_{k}, x_{m}\right)\right]}$ dla renty hipotecznej rodzaju SWŻ w krajach $\mathrm{z}$ największą bezwzględną

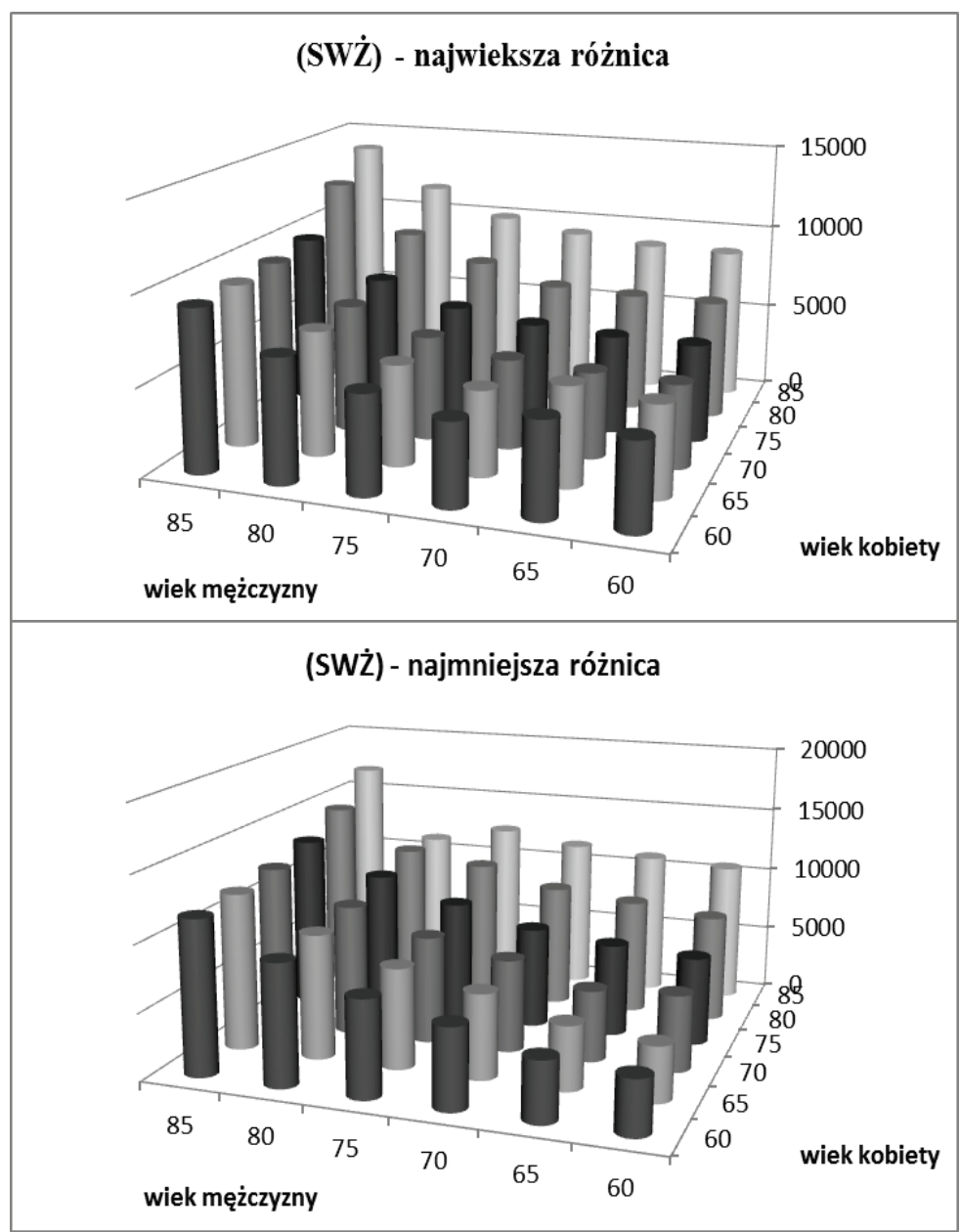

Rys. 5. Wysokość raty renty SWŻ w krajach z największą i najmniejszą bezwzględną różnicą między przeciętnym przyszłym czasem trwania życia żony i męża

Źródło: opracowanie własne. 
różnicą między przeciętnym przyszłym czasem trwania życia męża i

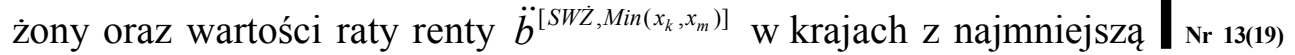
bezwzględną różnicą między przeciętnym przyszłym czasem trwania życia małżonków. Natomiast zmiany procentowe świadczeń w krajach z najmniejszą w stosunku do największej bezwzględnej różnicy między przeciętnym przyszłym czasem trwania życia małżonków, czyli wielkości

$$
\left(\frac{\ddot{b}^{\left[\operatorname{SWZ}, \operatorname{Min}\left(x_{k}, x_{m}\right)\right]}}{\ddot{b}^{\left[\operatorname{SWZ}, \operatorname{Max}\left(x_{k}, x_{m}\right)\right]}}-1\right) \cdot 100 \%,
$$

zostały przedstawione w tabeli 4 . Różnice te są większe w przypadku krajów, gdzie bezwzględna różnica między dalszym trwaniem życia kobiet i mężczyzn jest najmniejsza, tylko w pięciu przypadkach jest odwrotnie. Największa różnica bezwzględna między czasem trwania życia dla małżonków w wieku 75 lat jest we Francji (por. tabela 2), a najmniejsza dla Bułgarii (por. tabela 3 ). W tym przypadku świadczenie jest aż o 41\% wyższe dla małżeństwa bułgarskiego (największa różnica $\mathrm{w}$ wysokości świadczenia). Gdy mężczyzna jest w wieku 60 lat, a jego żona ma 65 lat, to największa bezwzględna różnica między przeciętnym przyszłym trwaniem życia małżonków jest na Litwie, a najmniejsza $\mathrm{w}$ Luksemburgu. W tym przypadku to małżeństwo z Litwy pobierałoby wyższe o $20 \%$ świadczenie.

Tabela 4. Różnica między wysokością świadczeń dla najmniejszej i największej bezwzględnej różnicy między trwaniem życia małżonków dla małżeńskiej renty hipotecznej rodzaju SWŻ

\begin{tabular}{|c|c|c|c|c|c|c|c|}
\hline & \multicolumn{6}{|c|}{ Wiek mężczyzny } \\
\hline & & 60 & 65 & 70 & 75 & 80 & 85 \\
\hline \multirow{6}{*}{ 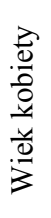 } & 60 & $-16 \%$ & $-15 \%$ & $29 \%$ & $30 \%$ & $31 \%$ & $27 \%$ \\
\hline & 65 & $-20 \%$ & $-14 \%$ & $32 \%$ & $32 \%$ & $32 \%$ & $28 \%$ \\
\hline & 70 & $20 \%$ & $9 \%$ & $36 \%$ & $36 \%$ & $35 \%$ & $30 \%$ \\
\hline & 75 & $19 \%$ & $25 \%$ & $30 \%$ & $41 \%$ & $40 \%$ & $34 \%$ \\
\hline & 80 & $19 \%$ & $28 \%$ & $34 \%$ & $33 \%$ & $21 \%$ & $18 \%$ \\
\hline & 85 & $22 \%$ & $25 \%$ & $25 \%$ & $25 \%$ & $-3 \%$ & $21 \%$ \\
\hline
\end{tabular}

Źródło: opracowanie własne.

Analogicznie jak na rys. 5, porównanie między wartościami świadczeń $\ddot{b}^{\left[S O P, \operatorname{Max}\left(x_{k}, x_{m}\right)\right]}$ dla renty hipotecznej rodzaju SOP w krajach z największą bezwzględną różnicą między przeciętnym przyszłym czasem trwania życia męża i żony oraz wartości raty renty 
$\ddot{b}^{\left[\operatorname{SOP}, \operatorname{Min}\left(x_{k}, x_{m}\right)\right]}$ w krajach z najmniejszą bezwzględną różnicą między

Nr 13(19) przeciętnym przyszłym czasem trwania życia małżonków zostało przedstawione na rys. 6. Natomiast zmiany procentowe świadczeń $\mathrm{w}$ krajach $\mathrm{z}$ najmniejszą $\mathrm{w}$ stosunku do największej bezwzględnej

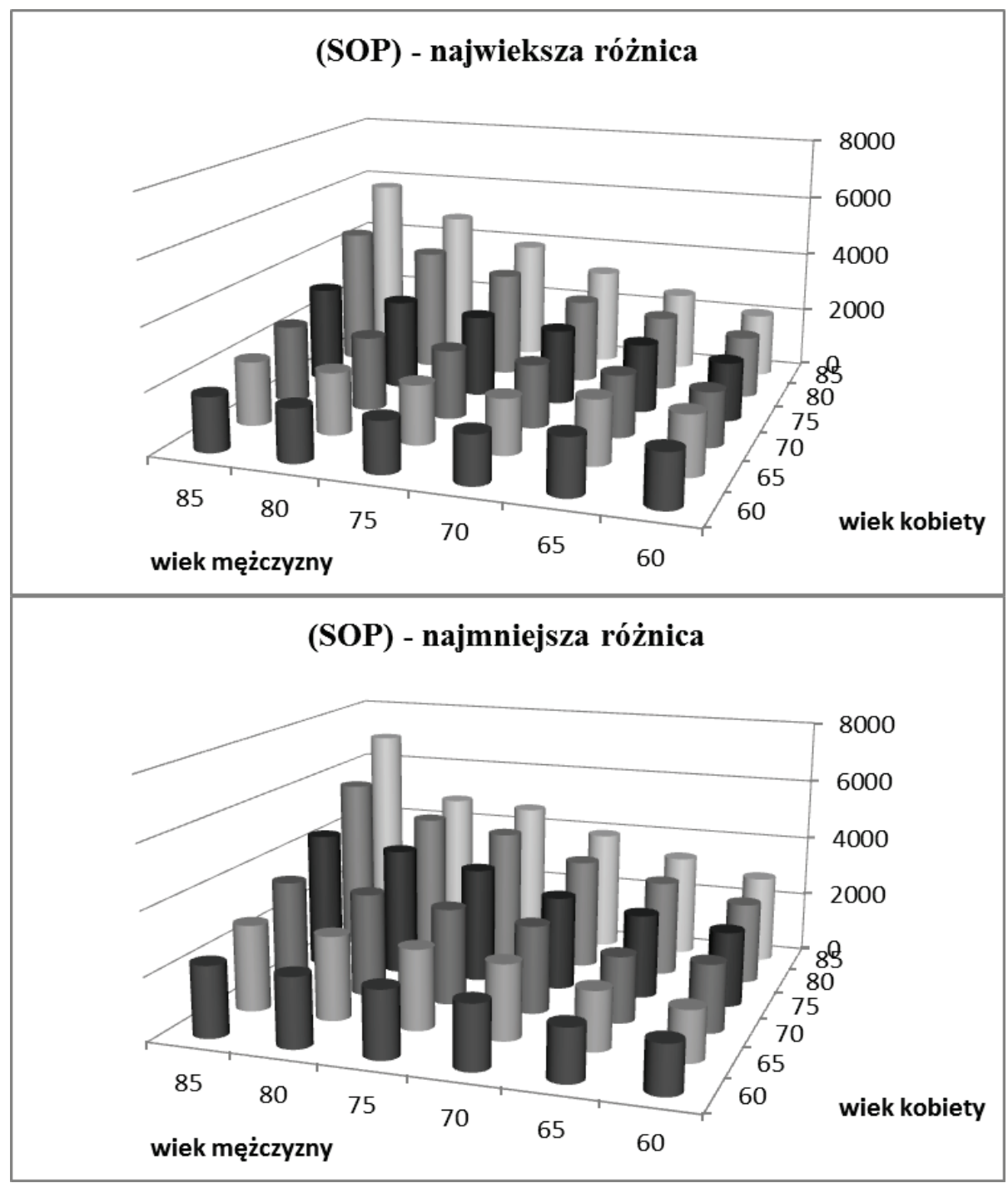

Rys. 6. Wysokość raty renty SOP w krajach z największą i najmniejszą bezwzględną różnicą między przeciętnym przyszłym czasem trwania życia żony i męża

Źródło: opracowanie własne. 
różnicy między przeciętnym przyszłym czasem trwania życia małżonków, czyli wielkości

$$
\left(\frac{\ddot{b}^{\left[\operatorname{SOP}, \operatorname{Min}\left(x_{k}, x_{m}\right)\right]}}{\ddot{b}^{\left[\operatorname{SOP}, \operatorname{Max}\left(x_{k}, x_{m}\right)\right]}}-1\right) \cdot 100 \%,
$$

zostały przedstawione w tabeli 5. Świadczenie rentowe dla renty rodzaju SOP w krajach, gdzie jest największa bezwzględna różnica między przeciętnym przyszłym trwaniem życia mężczyzn i kobiet jest wyższe, poza czterema przypadkami, dla małżeństw, gdy kobieta lub mężczyzna jest w wieku do 65 lat. Należy zauważyć, że gdy mężczyzna ma 60 lat, a jego żona jest w wieku 65 lat, to największa bezwzględna różnica między trwaniem życia małżonków jest na Litwie, a najmniejsza w Luksemburgu. W tym przypadku małżeństwo z Litwy pobiera wyższe świadczenie o 16\% (największa różnica w wysokości świadczenia). Jednak największą rozpiętość między świadczeniami obserwujemy w przypadku małżeństwa mężczyzny w wieku 85 lat z kobietą w wieku w wieku 75 lat. Oznacza to, że małżeństwo bułgarskie mogłoby liczyć na świadczenie rentowe aż o $42 \%$ wyższe niż małżeństwo we Francji.

Tabela 5. Różnica między wysokością świadczeń dla najmniejszej i największej bezwzględnej różnicy między trwaniem życia małżonków dla małżeńskiej renty hipotecznej rodzaju SOP

\begin{tabular}{|c|c|c|c|c|c|c|c|}
\hline & \multicolumn{6}{|c|}{ Wiek mężczyzny } \\
\hline & & 60 & 65 & 70 & 75 & 80 & 85 \\
\hline \multirow{6}{*}{$\begin{array}{l}\frac{2}{0} \\
0 \\
0 \\
0 \\
\frac{0}{0} \\
3\end{array}$} & 60 & $-10 \%$ & $-8 \%$ & $30 \%$ & $30 \%$ & $29 \%$ & $28 \%$ \\
\hline & 65 & $-16 \%$ & $-9 \%$ & $34 \%$ & $34 \%$ & $34 \%$ & $33 \%$ \\
\hline & 70 & $22 \%$ & $6 \%$ & $37 \%$ & $37 \%$ & $38 \%$ & $38 \%$ \\
\hline & 75 & $26 \%$ & $20 \%$ & $24 \%$ & $40 \%$ & $41 \%$ & $42 \%$ \\
\hline & 80 & $30 \%$ & $27 \%$ & $30 \%$ & $26 \%$ & $16 \%$ & $26 \%$ \\
\hline & 85 & $36 \%$ & $29 \%$ & $25 \%$ & $20 \%$ & $1 \%$ & $21 \%$ \\
\hline
\end{tabular}

Źródło: opracowanie własne.

\section{Podsumowanie}

$\mathrm{Na}$ wysokość świadczenia małżeńskiej renty hipotecznej wpływa przyszły czas trwania życia, a zatem i kraj, z którego pochodzą małżonkowie. Świadczenie jest najwyższe w krajach z najkrótszym czasem trwania życia, tj. w Bułgarii lub Bułgarii i Łotwie. Różnice w wysokości świadczeń między krajami UE są duże i sięgają nawet do $50 \%$. Ponadto rata renty wzrasta wraz z wiekiem małżonków. Ge- 
neralnie (poza kilkoma omówionymi przypadkami - małżeństw do 65 . roku życia) na wyższe świadczenie mogą liczyć małżonkowie z krajów, w których bezwzględna różnica między przeciętnym przyszłym czasem trwania ich życia jest jak najmniejsza.

$\mathrm{Na}$ wysokość świadczenia wpływa również rodzaj małżeńskiej renty hipotecznej. W przypadku statusu wspólnego trwania życia SWŻ świadczenie rentowe jest wyższe niż świadczenie, uzyskane z umowy rodzaju SOP. Niezależnie od wieku małżonków zakres zmienności świadczenia między małżeństwem z Francji (najdłuższy czas trwania życia), a Bułgarii lub Bułgarii i Łotwy (najkrótszy czas trwania życia) w przypadku umów rodzaju SWŻ jest dużo większy niż w przypadku umów rodzaju SOP. Dla rent hipotecznych rodzaju SWŻ wiek mężczyzny ma większy wpływ na wysokość świadczenia, odwrotnie niż w przypadku umów rodzaju SOP, gdzie to wiek kobiety ma większe znaczenie. 


\section{Załącznik 1}

Przeciętne dalsze trwanie życia kobiet $\mathrm{i}$ mężczyzn $e_{x_{k}}^{c}, \quad e_{x_{m}}^{c}$

$\left(x_{k}, x_{m} \in\{60,65,70,75,80,85\}\right)$ określone na bazie tablic trwania życia z 2009 roku.

\begin{tabular}{|c|c|c|c|c|c|c|c|c|c|c|c|c|}
\hline & \multicolumn{6}{|c|}{ WIEK KOBIET } & \multicolumn{6}{|c|}{ WIEK MĘŻCZYZN } \\
\hline $\operatorname{KRAJ}(c)$ & 60 & 65 & 70 & 75 & 80 & 85 & 60 & 65 & 70 & 75 & 80 & 85 \\
\hline Austria & 25,4 & 21,2 & 17,0 & 13,1 & 9,6 & 6,9 & 21,4 & 17,6 & 14,1 & 10,8 & 8,0 & 5,8 \\
\hline Belgia & 25,4 & 21,1 & 17,1 & 13,2 & 9,8 & 7,1 & 21,3 & 17,5 & 13,9 & 10,6 & 7,9 & 5,7 \\
\hline Bułgaria & 21,2 & 17,1 & 13,3 & 9,9 & 7,1 & 5,2 & 17,0 & 13,9 & 11,1 & 8,5 & 6,3 & 4,8 \\
\hline Cypr & 25,1 & 20,7 & 16,3 & 12,2 & 9,0 & 6,7 & 22,0 & 18 & 14,2 & 10,8 & 7,8 & 5,4 \\
\hline Czechy & 22,9 & 18,8 & 14,8 & 11,2 & 8,1 & 5,8 & 18,7 & 15,2 & 12,1 & 9,3 & 6,8 & 4,9 \\
\hline Dania & 23,6 & 19,5 & 15,6 & 12,1 & 9,1 & 6,5 & 20,6 & 16,8 & 13,2 & 10,0 & 7,4 & 5,3 \\
\hline Estonia & 23,4 & 19,3 & 15,3 & 11,7 & 8,6 & 6,2 & 17,2 & 14,1 & 11,3 & 8,9 & 6,8 & 5,1 \\
\hline Finlandia & 25,9 & 21,5 & 17,4 & 13,4 & 9,9 & 7,1 & 21,1 & 17,3 & 13,9 & 10,7 & 7,9 & 5,8 \\
\hline Francja & 27,5 & 23,2 & 18,9 & 14,9 & 11,2 & 8,2 & 22,5 & 18,7 & 15,1 & 11,7 & 8,8 & 6,5 \\
\hline Grecja & 25,3 & 20,8 & 16,5 & 12,5 & 9,0 & 6,5 & 21,8 & 17,9 & 14,2 & 10,9 & 8,0 & 5,9 \\
\hline Hiszpania & 27,0 & 22,5 & 18,1 & 14,0 & 10,4 & 7,5 & 22,2 & 18,3 & 14,6 & 11,3 & 8,4 & 6,2 \\
\hline Holandia & 25,3 & 21,0 & 16,9 & 13,1 & 9,7 & 7,0 & 21,6 & 17,6 & 13,8 & 10,5 & 7,8 & 5,7 \\
\hline Irlandia & 25,0 & 20,7 & 16,6 & 12,9 & 9,7 & 7,1 & 21,4 & 17,4 & 13,7 & 10,4 & 7,6 & 5,6 \\
\hline Litwa & 22,7 & 18,8 & 15,0 & 11,4 & 8,4 & 6,1 & 16,2 & 13,6 & 11,2 & 8,7 & 6,6 & 4,9 \\
\hline Luksemburg & 25,6 & 21,4 & 17,2 & 13,4 & 10,0 & 7,4 & 21,5 & 17,6 & 13,8 & 10,4 & 7,5 & 5,1 \\
\hline Łotwa & 21,9 & 18,1 & 14,3 & 10,9 & 8,0 & 5,9 & 15,9 & 13,2 & 10,7 & 8,4 & 6,5 & 5,0 \\
\hline Malta & 25,0 & 20,6 & 16,5 & 12,5 & 9,3 & 6,9 & 21 & 16,8 & 13,2 & 9,7 & 7,3 & 5,1 \\
\hline Niemcy & 25,1 & 20,8 & 16,6 & 12,7 & 9,3 & 6,7 & 21,5 & 17,6 & 14,1 & 10,9 & 8,2 & 6,3 \\
\hline Polska & 23,2 & 19,2 & 15,3 & 11,7 & 8,6 & 6,3 & 17,9 & 14,8 & 11,9 & 9,3 & 7,0 & 5,3 \\
\hline Portugalia & 25,2 & 20,8 & 16,5 & 12,6 & 9,1 & 6,5 & 21 & 17,2 & 13,6 & 10,3 & 7,5 & 5,5 \\
\hline Rumunia & 21,3 & 17,3 & 13,5 & 10,2 & 7,4 & 5,4 & 17,5 & 14,4 & 11,7 & 9,3 & 7,4 & 6,5 \\
\hline Słowacja & 22,1 & 18,0 & 14,1 & 10,7 & 7,7 & 5,6 & 17,3 & 14,1 & 11,2 & 8,7 & 6,5 & 4,9 \\
\hline Słowenia & 24,8 & 20,5 & 16,4 & 12,6 & 9,3 & 6,8 & 20,1 & 16,4 & 13,1 & 10,1 & 7,6 & 5,7 \\
\hline Szwecja & 25,5 & 21,2 & 17,1 & 13,2 & 9,7 & 6,9 & 22,4 & 18,2 & 14,4 & 10,9 & 8,0 & 5,6 \\
\hline Węgry & 22,1 & 18,2 & 14,5 & 11,1 & 8,3 & 6,3 & 16,9 & 14,0 & 11,3 & 8,9 & 6,9 & 5,5 \\
\hline Wielka Brytania & 25,0 & 20,7 & 16,7 & 13,0 & 9,8 & 7,2 & 22,0 & 18,0 & 14,3 & 11,1 & 8,2 & 6,1 \\
\hline Włochy & 26,2 & 21,8 & 17,6 & 13,6 & 10,0 & 7,1 & 22,1 & 18,1 & 14,3 & 10,9 & 7,9 & 5,7 \\
\hline
\end{tabular}

Źródło: Eurostat [www.epp.eurostat.ec.europa.eu (dostęp: 9.10.2014)]. 


$\begin{aligned} \begin{array}{r}\text { ŚLASKI } \\ \text { PRZEGLAD } \\ \text { STATYSTYCZNY }\end{array} & \text { Literatura } \\ \text { Nr 13(19) } & \text { Borys A., Odwrócona hipoteka i renta dożywotnia, warto czy nie?, 17.10.2013, }\end{aligned}$
http://www.polskieradio.pl/42/273/Artykul/958255, Odwrocona-hipoteka-i-renta-dozywotnia-warto-czy-nie.html [dostęp: 28.10.2013].

Dębicka J., An approach to the study of multistate insurance contracts, „Appl. Stochastic Models Bus. Ind.” 2013, Vol. 29, Issue 3,_s. 224-240.

Dębicka J., Modelowanie strumieni finansowych $w$ ubezpieczeniach wielostanowych, Wydawnictwo UE we Wrocławiu, Wrocław 2012.

Dębicka J., Marciniuk A., Comparison of reverse annuity contract and reverse mortgage on the Polish Market, 2014, http://onlinelibrary.wiley.com/doi/10.1002/asmb.1912.

Dębicka J., Marciniuk A., An approach to the study of multilife reverse annuity contracts - manuscript.

Dickson D.C.M., Hardy M.R., Waters H.R., Actuarial Mathematics for Life Contingent Risks. Cambridge University Press, Cambridge 2009.

Marciniuk A., Nielosowe modele natychmiastowej stopy procentowej i ich zastosowanie w klasycznych ubezpieczeniach życiowych, Ekonometria 27, Prace Naukowe Uniwersytetu Ekonomicznego we Wrocławiu nr 84, Wydawnictwo Uniwersytetu Ekonomicznego we Wrocławiu, Wrocław 2009, s. 112-127.

Marciniuk A., Renta hipoteczna a odwrócony kredyt hipoteczny na rynku polskim, Śląski Przegląd Statystyczny, nr 12(18), Wydawnictwo Uniwersytetu Ekonomicznego we Wrocławiu, Wrocław 2014, s. 253-272.

\section{Źródla internetowe}

Human Mortality Database. University of California, Berkeley (USA), and Max Planck Institute for Demographic Research (Germany), dostępne na: www.mortality.org; www.humanmortality.de.

Eurostat, dostępne na: www.epp.eurostat.ec.europa.eu

\section{COMPARATIVE ANALYSIS OF MARRIAGE REVERSE ANNUITY CONTRACTS IN THE COUNTRIES OF THE EUROPEAN UNION}

Summary: People live longer. Social insurance pensions are low and may be insufficient to survive with dignity. Therefore, new products appear on the market, which creates a possibility of obtaining additional financial resources. One of such products is called a reverse annuity contract. When the property owners are couples, an important issue is enabling the marriage reverse annuity contract when both spouses are alive, and then when one of them dies. The aim of this article is a comparative analysis of the amount of the marriage reverse annuity contract benefits in the countries of the European Union. In particular to determine the range of the size of annuity payments. For analysis of the amount of annuity benefits, countries in which the expected future life expectancy of men and women were the shortest and the longest a fixed age group of spouses was selected. In addition, the amount of annuities was analyzed in the countries where the absolute difference between the duration of the life of the spouses is the smallest and the largest. Poland is the country in which the expected future life expectancy of women and men, and the difference between these values is typical. Therefore, Poland was included in the analysis. In order to simplify the calculations, the matrix representation of formulas for annuity benefits is used. The analysis is based on Life Tables from the year 2009. All calculations were made using own interfaces written in MATLAB.

Keywords: marriage reverse annuity contract, status of the common life, status of the last surviving, multiple state model. 